Article

\title{
Critical Delaying Factors: Public Sector Building Projects in Gilgit-Baltistan, Pakistan
}

\author{
Shahid Hussain ${ }^{1, *}$ (D), Fangwei Zhu ${ }^{1, *}$, Zaigham Ali ${ }^{2}$, Hassan Danial Aslam ${ }^{3}$ \\ and Abasal Hussain 4 \\ 1 Faculty of Management and Economics, Dalian University of Technology, Dalian 116024, China \\ 2 Department of Business Management, Karakoram International University, Gilgit-Baltistan 15100, Pakistan; \\ zaigham.ali@kiu.edu.pk \\ 3 Department of Management Science, The Islamia University of Bahawalpur, Bahawalpur 63100, Pakistan; \\ hassan.danial@iub.edu.pk \\ 4 Department of Infrastructure Engineering, Dalian University of Technology, Dalian 116024, China; \\ ahhaider@mail.dlut.edu.cn \\ * Correspondence: shahidkhoja@mail.dlut.edu.cn (S.H.); zhufw@dlut.edu.cn (F.Z.)
}

Received: 20 November 2017; Accepted: 2 January 2018; Published: 3 January 2018

\begin{abstract}
Project delays are a large and prevalent problem in the Gilgit-Baltistan construction industry, and delays can distinctly affect project duration, budget, and also community needs. The purpose of this study is to highlight and rank delaying factors in the Annual Development Programme public sector building infrastructure projects and examine them through a relative importance index. A total of 52 delaying factors were identified through a detailed literature review and categorized into eight major groups, and a pilot study with 16 experienced construction experts was conducted. A questionnaire survey was conducted to collect the importance of each factor from public construction experts. In total, 102 respondents participated in the survey. The study determined that difficulties in financing projects by contractors, delays in progress payments, dispute on land usage, improper project feasibility studies, award project to the lowest bid price, extreme weather conditions, inadequate contractor experience, and insufficient data collection and survey before design were among the top eight critical delaying factors. In addition, Spearman's rank correlation tests revealed that there was no difference in perception between owners and contractors. A comparison of the top five delay factors was done with eight preferred construction industries in Asia to validate the results of this study. The findings are likely to be a solid contribution to the Gilgit-Baltistan construction industry in mitigating future construction delays.
\end{abstract}

Keywords: critical delaying factors; public sector; building infrastructure projects; Gilgit-Baltistan; Pakistan

\section{Introduction}

The construction industry plays an integral part in the advancement of any nation and the physical progress of construction projects including roads, buildings, power stations, and bridges is a measure of the economic upturn through which a society accomplishes its purpose and objectives of rural and urban advancement [1]. Public sector building construction projects are usually projected, and delays may occur during the project lifecycle. The delay is a situation when the owner and contractor mutually or separately contribute to the lack of completion of the project as specified in the original contract period [2]. Delays can be minimized when associated causes are clearly identified [3-5].

Gilgit-Baltistan (GB) is an autonomous self-governing northernmost political entity under the administrative control of Pakistan. The geographical remoteness, severe weather conditions, mountainous environment, and insufficiency of resources contribute to the region's continuing socioeconomic backwardness. In recent years, the Gilgit-Baltistan Public Work Department (GBPWD) 
has played a fundamental role in reforming and boosting public infrastructure in GB. The construction delay is unfavorable for developing countries especially in Pakistan, but no suitable research has been done in the case of GB Pakistan to provide a significant successful way to construction players for Annual Development Programme (ADP) projects. ADP construction projects in GB are managed by the GBPWD, which is primarily responsible for design-bid-build construction projects. GB ADP increased by $51.23 \%$ year-on-year from 8100 million Pakistani Rupees (PKR) in 2014-2015 to 12,250 million PKR in 2015-2016 (1 US \$ = 109 PKR in December 2017). The government of GB ADP contributes to the development of buildings infrastructure projects (e.g., hospitals, educational institutions, government residences) in numerous ways for the benefit and sustainability of the community [6]. GB ADP allocates budgets for ongoing as well as new public-sector buildings infrastructure projects in order to solve the public problems and improve the better quality of life for its inhabitants [6].

However, project delays are a common and repetitive occurrence in the GB construction industry because of an unstable economy, political situation, and remoteness. These problems of delay include construction projects funded by the government budget. With the demanding building project development in GB to sustain its economic growth, it is essential to investigate the stakeholders (owner, contractor) of building infrastructure projects to more improved and more suitable execution so that construction projects can be completed on time, within budget and with high quality. Therefore, it is important to research and explores the critical causes of delays during construction/execution phase of projects in GB Pakistan. This paper focuses on the critical delaying factors of small size building construction projects of the Pakistani public construction industry.

The following sections describe the literature review and objectives of the study, the methodology used in this study, data analysis, results, discussion of the results and conclusion and recommendation of the study.

\section{Literature Review}

Understanding delaying factors allow owners and contractors to reduce the impacts of such delays on their projects. Identification and assessment of delay factors are necessary yet challenging. There is a need to prioritize such significant delay factors. In construction projects, the delay is defined as an act or event that prolongs the time and budget limit specified for deliverables under the contract that the parties agreed upon $[7,8]$.

Kaliba et al. [9] studied in Zambia and identified delay payments, inappropriate financial process and difficulties, contract modification and economic problems as causes of delays. Kim et al. [10] found that major delaying factors in Vietnam were financial difficulties on the part of the owner, a lack of supervisor responsibility, design change by the owner, incompetence on the part of the contractor, and inadequate contractor experience. In addition, the study recommended solutions for resolving the project delay.

Ye et al. [11], Khoshgoftar et al. [12], Gündüz et al. [13], Abdul-Rahman et al. [14], and Yang and Shen-Fen [15] categorically discussed significant delays causes and proposed valuable recommendations to improve the construction industry in a particular study area. Construction projects operations are not trivial due to the complexities of construction processes. Moreover, the various external interferences are reported in project construction phases $[7,16]$.

Various published studies in different countries on construction project delaying factors [7,8,13,17-25] identified most important delay causes as follows: the financing and payment of completed work by the owner, inadequate contractor experience, design changes by the owner or their agent during construction, poor site management and supervision by the contractor, as well as too many change orders made by the owner. The researchers justified that delays causes time overrun, schedule overrun, and cost overrun in the construction projects and their results emphasized the need to bring improvement to the construction industry. However, due to country-specific regional, geographical and administrative differences, researchers are still attempting to adequately describe the causes of project delays $[7,20]$. 
Thus, different patterns of delay causes were identified in various studies. Many studies have focused on a general construction project $[8,13,24]$, and very few studies focused on public funding projects [26-28]. However, the delay of ADP public sector building projects has not been examined in previous researches, based on authors' information; hence, this study survey and investigate these factors which cause delays in public sector building projects. To fill this knowledge gap, this study aims at the identification of ADP public sector building projects critical delaying factors especially in the project execution phase of a project in GB, Pakistan. There is a strong need to find out the delaying factors, which are still uncharted in the GB construction industry. The GB is one of the most inaccessible and remote areas of the country with paucity educational, health, communication and transportation facilities. GB ADP construction projects have been troubled for several years and frequently experience cost escalation and time overrun, which encourages us to undertake this study in the region. The contribution of this study is that it can provide a deep focus on the critical delaying factors that affect public sector building projects in the region. Furthermore, it provides a broader scope of comparisons from different views to provide a vibrant idea about all aspects that delay building projects. The suggestions of this study will permit different project participants to execute the projects without any delays and meet project goals.

Below is a list of some statistics about twelve years of ADP construction projects delay provided by the GBPWD reports (The Office of Planning and Development Department, December 2016).

Table 1 shows data regarding ADP construction projects delay in GB under the supervision of GBPWD, where owners were expected to finish the projects in one to two years, and significant delays were revealed. The survey revealed that $70 \%$ of the building projects behind planned schedule and cost, whereas only $30 \%$ were completed within time and estimated budget (Source: Planning and Finance Department, GB; 2016).

Table 1. Annual Development Programme (ADP) construction Projects Delay List in Gilgit-Baltistan (GB).

\begin{tabular}{|c|c|c|c|c|c|}
\hline $\begin{array}{l}\text { ADP No. } \\
\text { (2016) }\end{array}$ & Project Name & $\begin{array}{l}\text { Approved Cost } \\
\text { (PKR Million) }\end{array}$ & $\begin{array}{l}\text { Date of Start } \\
(\mathrm{M}-\mathrm{Y})\end{array}$ & $\begin{array}{l}\text { Expected Date } \\
\text { of Completion }\end{array}$ & $\begin{array}{c}\text { Project } \\
\text { Delayed }\end{array}$ \\
\hline 497 & $\begin{array}{l}\text { Construction of residential } \\
\text { Accommodation for Officers in } \\
\text { Northern Areas }\end{array}$ & 196.00 & Apr-05 & Feb-07 & Still in progress \\
\hline 07 & $\begin{array}{l}\text { Residential/Non-residential } \\
\text { Accommodation for Northern Areas } \\
\text { Police Reserve Force }\end{array}$ & 150.00 & Sep-06 & Aug-08 & Still in progress \\
\hline 397 & $\begin{array}{l}\text { Upgrade of 30-bed Hospital into } \\
\text { 50-bed at Kashrote, Gilgit }\end{array}$ & 120.00 & Jun-06 & Jun-08 & Still in progress \\
\hline 411 & $\begin{array}{l}\text { Construction of 100-bed District } \\
\text { Headquarter Hospital Main Complex }\end{array}$ & 109.88 & Nov-05 & Oct-07 & Still in progress \\
\hline 496 & $\begin{array}{l}\text { Construction residential } \\
\text { accommodation for speaker and } \\
\text { deputy chief executive and staff } \\
\text { Northern Areas }\end{array}$ & 96.00 & Jun-05 & Aug-07 & Still in progress \\
\hline 494 & $\begin{array}{l}\text { Construction of staff colony for the } \\
\text { employees of Northern Areas at Gilgit }\end{array}$ & 80.00 & May-05 & Aug-07 & Still in progress \\
\hline 43 & $\begin{array}{l}\text { Concoction of Non-residential } \\
\text { accommodation for police in Diamer }\end{array}$ & 82.64 & Nov-06 & Mar-08 & Still in progress \\
\hline 306 & $\begin{array}{l}\text { Strengthening of F.G College of } \\
\text { Education Jutial Gilgi }\end{array}$ & 62.50 & Oct-10 & & Still in progress \\
\hline 244 & $\begin{array}{l}\text { Establishment of } \\
\text { Technical/Vocational Training } \\
\text { Institute in Gilgit-Baltistan }\end{array}$ & 59.99 & Feb-13 & Dec-14 & Still in progress \\
\hline 65 & $\begin{array}{l}\text { Construction Court Building and } \\
\text { Residential accommodation for } \\
\text { Session Judge Diamer }\end{array}$ & 58.00 & Jun-10 & Sep-12 & Still in progress \\
\hline 441 & $\begin{array}{l}\text { Construction of 10-bed hospital at } \\
\text { Chilum Astore }\end{array}$ & 32.07 & Apr-13 & Apr-15 & Still in progress \\
\hline
\end{tabular}


Table 1. Cont.

\begin{tabular}{clcccc}
\hline $\begin{array}{c}\text { ADP No. } \\
\text { (2016) }\end{array}$ & \multicolumn{1}{c}{ Project Name } & $\begin{array}{c}\text { Approved Cost } \\
\text { (PKR Million) }\end{array}$ & $\begin{array}{c}\text { Date of Start } \\
\text { (M-Y) }\end{array}$ & $\begin{array}{c}\text { Expected Date } \\
\text { of Completion }\end{array}$ & $\begin{array}{c}\text { Project } \\
\text { Delayed }\end{array}$ \\
\hline 245 & $\begin{array}{l}\text { Construction of mineralogical section } \\
\text { of the minerals testing laboratory }\end{array}$ & 27.40 & Dec-11 & Dec-13 & Still in progress \\
\hline 303 & $\begin{array}{l}\text { Scholarship for Professional Colleges } \\
\text { (Engineering and Medical) }\end{array}$ & 60.00 & Dec-05 & Nov-07 & Still in progress \\
\hline 437 & $\begin{array}{l}\text { Improvement/Rehabilitation and } \\
\text { Provision of Missing Facilities for } \\
\text { District Ghanche }\end{array}$ & 20.00 & Sep-14 & Oct-16 & Still in progress \\
\hline 365 & $\begin{array}{l}\text { Construction of Inter College } \\
\text { at Chatorkhand }\end{array}$ & 16.00 & Feb-02 & Sep-04 & Still in progress \\
\hline
\end{tabular}

\section{Objectives of the Study}

The primary objectives of this study include the following:

- To identify the critical delaying factors in ADP building projects in the GB, Pakistan.

- To identify the relative importance of critical delaying factors of owners and contractors and group them according to their importance level of critical delays.

- To identify the relative differences in perceptions of both owners and contractors.

- To compare the GB construction situation with some preferred Asian countries.

\section{Research Methodology}

The scope of this study covered ADP public sector building projects (e.g., hospitals, educational institutions, government residences) which is administrated by PWD in GB, Pakistan. As revealed in the literature review, the delay causes in construction could be supposed to be generic; though, some are project and country-specific. Several aspects of construction delay in the GBPWD construction industry drawing from numerous worldwide researchers stated in the literature review. To identify the critical delaying factors in GB construction industry, a detailed literature review and discussion with specialists involved in GB construction industry were performed and develop a survey questionnaire. An initially conducted pilot study $[3,24,26,29]$ and face-to-face interviews were conducted from 16 respondents having more than 14 years' professional experience in public sector construction projects. All respondents confirmed that the questionnaire was adequate for determining the delaying factors in the GB Pakistan context. The questionnaire was randomly circulated among owners and contractors in the GB construction industry and was personally handed to the respondents.

The format of the questionnaire was divided into two sections. The first section consisted of the demographics of the respondents. The second section was the main body of the questionnaire and was comprised of the eight groups (project group, owner group, contractor group, design group, equipment group, material group, labor group and external group) and 52 sub-questions. A five-point Likert scale from 5 (very high effect) to 1 (very little effect) was adopted to gauge the respondents' opinions.

The total of 120 questionnaires were distributed to construction practitioners (70 to owners, and 50 to contractors). A total of 102 sets $(85 \%)$ were returned, 58 sets $(82.86 \%)$ from owners and 44 sets $(88 \%)$ from contractors, respectively. The data were analyzed using the statistical tool relative importance index (RII) method which ranks the different critical delaying factors. Moreover, Spearman's rank correlation $\left(r_{s}\right)$ was used to test the degree of agreement or disagreement in the ranking of the significant delaying factors between the owners and contractors. Finally, the analysis explained factors and groups rank based on RII values that are most critical in the ranking list. 


\section{Data Analysis}

\subsection{Ranking of the Critical Delaying Factors}

Khoshgoftar [12], El-Razek [18], Olawale [30], and Akogbe [31] have applied the RII method to determine the ranking of the different delay factors. In this study, the authors also applied the same method to determine the relative importance. The RII was calculated using the following formula:

$$
\mathrm{RII}=\left(\sum \mathrm{W}\right) /\left(\mathrm{A}^{*} \mathrm{~N}\right)
$$

where RII is the relative importance index, $\mathrm{W}$ is the weight given to each factor by the respondents (ranging from 1 to 5), $\mathrm{A}$ is the highest weight (5 in this case), and $\mathrm{N}$ is the total number of respondents. The RII had a range from 0 to 1 ( 0 not inclusive). The greater the RII value, the more significant the cause of the critical delay was.

\subsection{Spearman's Rank Correlation}

In this study, the Spearman's correlation $\left(r_{s}\right)$ is used $[18,26,32,33]$ to evaluate and compare the degree of agreement or disagreement between the owners and contractors on the critical delaying factors. The $r_{s}$ values vary between +1 and -1 .

The $r_{s}[34]$ is used to measure by the following formula:

$$
r_{s}=\left(6 \sum d^{2}\right) / n\left(n^{2}-1\right)
$$

where $r_{s}=$ Spearman rank correlation coefficient between two parties, $d=$ difference between ranks assigned to each factor, and $n=$ the number of pairs of rank.

\section{Results}

\subsection{General Characteristics of Respondents}

Owners were government officials (superintendent engineers, executive engineers, sub-engineers, designers) and registered contractors [35] (Engineering Works Bylaw 4 and 8) with Pakistan Engineering Council (PEC) that had valid registration licenses. PEC is a federal statutory institution constituted under the PEC Act of 1976. Furthermore, most of the respondents were qualified and experienced in their relevant field, which validates the findings. The demographic characteristics of the respondents are shown in Table 2.

Table 2. Demographic Characteristics of the Respondents.

\begin{tabular}{cccc}
\hline Characteristics & \multicolumn{1}{c}{ Frequency (Owner) and (\%) } & Frequency (Contractor) and (\%) & Combined (\%) \\
\hline \multicolumn{5}{c}{ Gender } \\
\hline Male & 58 & 44 & 102 \\
Female & 0 & 0 & 0 \\
\hline \multicolumn{5}{c}{ Age } \\
\hline $21-30$ & $7(12 \%)$ & 0 & $7(6.8 \%)$ \\
$41-40$ & $31(53.5 \%)$ & $21(48 \%)$ & $52(51 \%)$ \\
$>50$ & $9(15.5 \%)$ & $11(25 \%)$ & $20(19.6 \%)$ \\
& $11(19 \%)$ & $12(27 \%)$ & $23(22.6 \%)$ \\
\hline $06-10$ & & Experience & $20(19.6 \%)$ \\
$11-15$ & $13(22.5 \%)$ & $7(16 \%)$ & $34(33.4 \%)$ \\
$16-20$ & $18(31 \%)$ & $16(36 \%)$ & $19(18.6 \%)$ \\
$>20$ & $10(17 \%)$ & $9(21 \%)$ & $29(28.4 \%)$ \\
\hline
\end{tabular}


Table 2. Cont.

\begin{tabular}{cccc}
\hline Characteristics & Frequency (Owner) and (\%) & Frequency (Contractor) and (\%) & Combined (\%) \\
\hline \multicolumn{4}{c}{ Education } \\
\hline Diploma in Civil Eng. & $34(58.6 \%)$ & 0 & $34(33 \%)$ \\
B.Sc./B.A. & $22(38 \%)$ & $39(88.6)$ & $61(60 \%)$ \\
M.Sc. & $1(1.7 \%)$ & $5(11.4 \%)$ & $6(6 \%)$ \\
Ph.D. & $1(1.7 \%)$ & 0 & $1(1 \%)$ \\
\hline
\end{tabular}

\subsection{Ranking of Critical Delaying Factors}

Table 3 shows the critical delaying factors related to the owners' and contractors' feedback which were separated and examined individually and ranked based on RII values. Furthermore, an individual view of both owners and contractors on delaying factors helps to identify the most critical significant delaying factors.

Table 3. Relative Importance Index (RII) Value and Ranking of Critical Delaying Factors.

\begin{tabular}{|c|c|c|c|c|c|c|}
\hline \multirow{2}{*}{ Critical Delaying Factors } & \multicolumn{2}{|c|}{ Combined View } & \multicolumn{2}{|c|}{ Owners' View } & \multicolumn{2}{|c|}{ Contractors' View } \\
\hline & RII & Rank & RII & Rank & RII & Rank \\
\hline \multicolumn{7}{|c|}{ Project Group } \\
\hline Original contract duration is too short & 0.525 & 20 & 0.545 & 23 & 0.500 & 13 \\
\hline Legal disputes between owner and contractor & 0.457 & 39 & 0.490 & 39 & 0.414 & 34 \\
\hline Rework due to change of design or deviation order & 0.527 & 17 & 0.538 & 24 & 0.514 & 11 \\
\hline Award project to the lowest bid price & 0.622 & 5 & 0.659 & 5 & 0.573 & 7 \\
\hline \multicolumn{7}{|c|}{ Owner Group } \\
\hline Delay in progress payments & 0.688 & 2 & 0.659 & 5 & 0.727 & 1 \\
\hline Delay in finance and payments of completed work & 0.553 & 10 & 0.514 & 33 & 0.605 & 4 \\
\hline Change order by owner during construction & 0.486 & 30 & 0.528 & 28 & 0.432 & 28 \\
\hline Delay to furnish and deliver the site to the contractor & 0.512 & 24 & 0.559 & 18 & 0.450 & 19 \\
\hline $\begin{array}{l}\text { Late in revising and approving design documents by } \\
\text { owner }\end{array}$ & 0.471 & 32 & 0.534 & 25 & 0.386 & 45 \\
\hline $\begin{array}{l}\text { Poor communication and coordination by owner and } \\
\text { contractor }\end{array}$ & 0.420 & 47 & 0.452 & 48 & 0.377 & 48 \\
\hline Slowness in decision making process by owner & 0.488 & 29 & 0.517 & 30 & 0.450 & 19 \\
\hline $\begin{array}{l}\text { Variation orders/changes of scope by owner during } \\
\text { construction }\end{array}$ & 0.471 & 32 & 0.517 & 30 & 0.409 & 35 \\
\hline Delay in approval of completed work by owner & 0.478 & 31 & 0.503 & 35 & 0.445 & 24 \\
\hline Payment procedure is complex & 0.490 & 28 & 0.476 & 42 & 0.509 & 12 \\
\hline Evaluation of completed works & 0.392 & 52 & 0.372 & 52 & 0.418 & 32 \\
\hline Improper project feasibility study & 0.661 & 4 & 0.721 & 2 & 0.582 & 6 \\
\hline Delay in running bill payments to the contractor & 0.549 & 11 & 0.531 & 27 & 0.573 & 7 \\
\hline \multicolumn{7}{|c|}{ Contractor Group } \\
\hline Difficulties in financing project by contractor & 0.702 & 1 & 0.752 & 1 & 0.636 & 3 \\
\hline Rework due to error in execution & 0.496 & 27 & 0.548 & 22 & 0.427 & 30 \\
\hline Poor site management and supervision by contractor & 0.533 & 14 & 0.628 & 9 & 0.409 & 35 \\
\hline $\begin{array}{l}\text { Ineffective planning and scheduling of project } \\
\text { by contractor }\end{array}$ & 0.575 & 9 & 0.662 & 4 & 0.459 & 17 \\
\hline $\begin{array}{l}\text { Improper construction methods implemented } \\
\text { by contractor }\end{array}$ & 0.500 & 25 & 0.555 & 20 & 0.427 & 30 \\
\hline Delay in site mobilization & 0.518 & 22 & 0.593 & 14 & 0.418 & 32 \\
\hline Non-availability of suitable contractors & 0.471 & 32 & 0.517 & 30 & 0.409 & 35 \\
\hline Poor qualification of the contractor technical staff & 0.531 & 16 & 0.593 & 14 & 0.450 & 19 \\
\hline Inadequate contractor experience & 0.594 & 7 & 0.641 & 7 & 0.532 & 9 \\
\hline Incompetent project team & 0.537 & 12 & 0.610 & 11 & 0.441 & 26 \\
\hline
\end{tabular}


Table 3. Cont.

\begin{tabular}{|c|c|c|c|c|c|c|}
\hline \multirow{2}{*}{ Critical Delaying Factors } & \multicolumn{2}{|c|}{ Combined View } & \multicolumn{2}{|c|}{ Owners' View } & \multicolumn{2}{|c|}{ Contractors' View } \\
\hline & RII & Rank & RII & Rank & RII & Rank \\
\hline \multicolumn{7}{|c|}{ Design Group } \\
\hline Mistakes and discrepancies in design documents & 0.498 & 26 & 0.534 & 25 & 0.450 & 19 \\
\hline Delays in producing design documents & 0.465 & 37 & 0.507 & 34 & 0.409 & 35 \\
\hline Unclear and inadequate details in drawings & 0.449 & 43 & 0.479 & 41 & 0.409 & 35 \\
\hline Insufficient data collection and survey before design & 0.582 & 8 & 0.624 & 10 & 0.527 & 10 \\
\hline $\begin{array}{l}\text { Misunderstanding of owner's requirements by } \\
\text { design engineer }\end{array}$ & 0.416 & 49 & 0.466 & 44 & 0.350 & 50 \\
\hline Inadequate design team experience & 0.467 & 36 & 0.524 & 29 & 0.391 & 43 \\
\hline Complexity of project design & 0.406 & 50 & 0.448 & 49 & 0.350 & 50 \\
\hline \multicolumn{6}{|c|}{ Material Group } & 24 \\
\hline $\begin{array}{l}\text { Changes in material types and specifications during } \\
\text { construction }\end{array}$ & 0.457 & 39 & 0.493 & 38 & 0.409 & 35 \\
\hline Shortage of construction materials in market & 0.527 & 17 & 0.552 & 21 & 0.495 & 14 \\
\hline Delay in material delivery & 0.435 & 44 & 0.483 & 40 & 0.373 & 49 \\
\hline Late procurement of materials & 0.418 & 48 & 0.472 & 43 & 0.345 & 52 \\
\hline Change in material prices or price escalation & 0.537 & 12 & 0.590 & 17 & 0.468 & 15 \\
\hline \multicolumn{7}{|c|}{ Equipment Group } \\
\hline Shortage of equipment & 0.514 & 23 & 0.597 & 12 & 0.405 & 41 \\
\hline Lack of high technology mechanical equipment & 0.520 & 21 & 0.559 & 18 & 0.468 & 15 \\
\hline Lack of skilled operators for specialized equipment & 0.527 & 17 & 0.593 & 14 & 0.441 & 26 \\
\hline \multicolumn{7}{|c|}{ Labor Group } \\
\hline Shortage of labor & 0.429 & 45 & 0.466 & 44 & 0.382 & 47 \\
\hline Unqualified/inexperienced labor & 0.453 & 41 & 0.500 & 36 & 0.391 & 43 \\
\hline Low productivity level of labor & 0.422 & 46 & 0.448 & 49 & 0.386 & 45 \\
\hline \multicolumn{7}{|c|}{ External Group } \\
\hline $\begin{array}{l}\text { Effects of subsurface conditions (e.g., soil, high water } \\
\text { table, etc.) }\end{array}$ & 0.461 & 38 & 0.462 & 46 & 0.459 & 17 \\
\hline Changes in government regulations and laws & 0.400 & 51 & 0.397 & 51 & 0.405 & 41 \\
\hline Extreme weather conditions & 0.616 & 6 & 0.638 & 8 & 0.586 & 5 \\
\hline Political/bureaucratic influences & 0.533 & 14 & 0.597 & 12 & 0.450 & 19 \\
\hline Natural disasters (flood, hurricane, earthquake) & 0.469 & 35 & 0.497 & 37 & 0.432 & 28 \\
\hline Dispute on land usage & 0.680 & 3 & 0.700 & 3 & 0.655 & 2 \\
\hline
\end{tabular}

\subsection{Top Eight Most Critical Delaying Factors from Combined View}

The combined views (owners and contractors) of the top eight delaying factors are showed in Table 3, and includes difficulties in financing project by contractor (RII $=0.702)$, delay in progress payments $(\mathrm{RII}=0.688)$, dispute on land usage $(\mathrm{RII}=0.680)$, improper project feasibility study $(\mathrm{RII}=0.661)$, award project to the lowest bid price $(\mathrm{RII}=0.622)$, extreme weather conditions $(\mathrm{RII}=0.616)$, inadequate contractor experience $(\mathrm{RII}=0.594)$, and insufficient data collection and survey before design $(\mathrm{RII}=0.582)$. It can be concluded from Table 3 that only two factors were related to the project and design group, while the other six factors were related to the contractor, owner, and external groups. Table 3 also shows that five out of the top eight delaying factors were similar between owners and contractors.

\subsection{Analysis and Ranking of Overall Results by Delay Causes Groups}

The group RII was computed as the average of the importance indices for the critical delaying factors in the groups and the rank of all eight groups according to their relative importance is shown in 
Table 4. A concise explanation of the ranking of groups according to the RII of critical delaying factors follows below.

Table 4. Importance Index and Ranking of Major Delays in Groups.

\begin{tabular}{ccccccc}
\hline \multirow{2}{*}{ Groups } & \multicolumn{2}{c}{ Combined View } & \multicolumn{2}{c}{ Owners' View } & \multicolumn{2}{c}{ Contractors' View } \\
\cline { 2 - 7 } & RII & Rank & RII & Rank & RII & Rank \\
\hline Contractor & 0.537 & 1 & 0.610 & 1 & 0.464 & 4 \\
Project & 0.529 & 2 & 0.558 & 3 & 0.500 & 1 \\
External & 0.523 & 3 & 0.548 & 4 & 0.498 & 2 \\
Equipment & 0.510 & 4 & 0.583 & 2 & 0.438 & 5 \\
Owner & 0.509 & 5 & 0.529 & 5 & 0.490 & 3 \\
Material & 0.468 & 6 & 0.518 & 6 & 0.418 & 6 \\
Design & 0.461 & 7 & 0.505 & 7 & 0.416 & 7 \\
Labor & 0.429 & 8 & 0.471 & 8 & 0.386 & 8 \\
\hline
\end{tabular}

\subsubsection{Contractor Group (10 Attributes)}

Table 4 shows both owners and contractors ranking of delay factors. Owners and contractors both ranked $(\mathrm{RII}=0.537)$ this group very high. The respondents' opinions were moderately similar and agreed that this group attributes lead to project delays and have a large effect on the construction progress. It is worth noting that "difficulties in financing project by contractor" was ranked as a significant cause of delay by contractors. The top three most delaying factors from combined views were difficulties in financing project by the contractor $(\mathrm{RII}=0.702)$, inadequate contractor experience $(\mathrm{RII}=0.608)$, and ineffective planning and scheduling of project by the contractor $(\mathrm{RII}=0.575)$. The degree of agreement between owners and contractors for this group was $r_{s}=0.78$.

\subsubsection{Project Group (Four Attributes)}

The study found that the project group $(\mathrm{RII}=0.529)$ was the second-most important group to cause critical delays. Owners and contractors' views were quite similar, and both agreed that the project group delaying factors were significant factors. There was no difference in the ranking of the owners and contractors' opinions. The three most significant critical delaying factors from combined views related to project group were award project to the lowest bid price $(\mathrm{RII}=0.622)$, rework due to change of design or deviation order ( $\mathrm{RII}=0.527)$, and original contract duration is too short $(\mathrm{RII}=0.525)$. The degree of agreement between owners and contractors for this group was $r_{s}=0.80$.

\subsubsection{External Group (Six Attributes)}

Table 4 shows that the third most important group of critical delaying factors was an external group $(\mathrm{RII}=0.523)$. Owners ranked this group's delaying factors as somewhat important, but the contractors ranked it higher. However, there were no differences in ranking between owners and contractors for this group's attributes except for "effects of subsurface conditions." The combined view of the top three significant factors related to this group was a dispute on land usage (RII $=0.680$ ), extreme weather conditions ( $\mathrm{RII}=0.616$ ), and political/bureaucratic influences (RII $=0.533)$. There is a high degree of agreement between the owners and contractors: i.e., $r_{s}=0.83$.

\subsubsection{Equipment Group (Three Attributes)}

Table 4 shows both owners and contractors ranked this group fourth $(\mathrm{RII}=0.510)$ in the group ranking. This group was ranked highly by owners and was ranked poorly by contractors. It is notable, however, that both owners and contractors have contrary views of this group's attributes. The top three factors related were a shortage of equipment $(\mathrm{RII}=0.514)$, lack of high technology mechanical equipment $(\mathrm{RII}=0.520)$, and lack of skilled operators for specialized equipment $(\mathrm{RII}=0.527)$. 
The degree of agreement between owners and contractors, that is, $r_{s}=-1$ for this group. Owners and contractors have opposite views regarding this group.

\subsubsection{Owner Group (13 Attributes)}

Table 4 shows the owner group $(\mathrm{RII}=0.509)$ was ranked fifth by both owners and contractors. This group's critical delaying factors were ranked high by contractors, and comparatively low by owners. This is possible because contractors face difficulties related to the payments and payments procedures during construction. The top three most delaying factors in the GB construction industry related to the owner group was delay in progress payments $(\mathrm{RII}=0.688)$, improper project feasibility study $(\mathrm{RII}=0.661)$, and delay in finance and payments of completed work $(\mathrm{RII}=0.553)$. The degree of agreement between owners and contractors for this group was $r_{s}=0.44$.

\subsubsection{Material Group (Five Attributes)}

Table 4 shows that the combined view of owners and contractors ranked this group in the sixth position with RII $=0.468$. This group of delaying factors was ranked comparatively low by both owners and contractors. Respondents agreed that this group's attributes led to project delays but had a low effect on construction progress. The top three most critical delaying factors from the combined view were: change in material prices or price escalation ( $\mathrm{RII}=0.537$ ); shortage of construction materials in the market $(\mathrm{RII}=0.527)$, and; changes in material types and specifications during construction $(\mathrm{RII}=0.457)$. The degree of agreement between owners and contractors for this group was $r_{s}=0.90$.

\subsubsection{Design Group (Eight Attributes)}

Table 4 shows that this group was ranked seventh from the combined views with RII $=0.461$. This group's delaying factors were ranked with comparatively low significance by the respondents. It is worth noting that owners agreed that "insufficient data collection and survey before design" was the most significant delaying factor in the GB construction industry. The result shows that insufficient data collection and survey before design $(\mathrm{RII}=0.582)$, mistakes and discrepancies in design documents $(\mathrm{RII}=0.498)$, and inadequate design team experience $(\mathrm{RII}=0.467)$ were the top three most critical delaying factors from the owners' and contractors' combined view. The degree of agreement between owners and contractors for this group was $r_{s}=0.67$.

\subsubsection{Labor Group (FourAttributes)}

Table 4 shows that the labor group was last in the group ranking from the combined view with RII $=0.429$. Both owners and contractors ranked this group the lowest. The owners accepted that shortage of labor was a significant delay factor, whereas contractors ranked it as a somewhat significant issue, which shows that owners and contractors had opposing views. The top three most critical delaying factors were unqualified/inexperienced labor $(\mathrm{RII}=0.453)$, shortage of labor $(\mathrm{RII}=0.429)$, and low productivity level of labor $(\mathrm{RII}=0.422)$. The degree of agreement between owners and contractors for this group was $r_{s}=-1$.

\section{Comparison of Owners' and Contractors' Views}

Owners and contractors view critical delaying factors differently. Owners look at the delaying factors starting from project initiation until its completion. The primary aim of owners is to determine the solution to the factors that cause serious project delays within a project's terms and conditions. In contrary, a contractor's primary focus is on receiving payments, recurring budget, and minimizing the expenditure of project activities to maximize the profit. According to Table 3, owners ranked "Difficulties in financing project by contractor" first, but contractors ranked it third. This shows that the contractors were not financially strong and had finance shortages when investing in projects. If contractors face financial difficulties, project progress will suffer. "Delay in progress payments" 
was ranked first by contractors and ranked fifth by owners. This was due to inefficient planning for funds in the current fiscal year for ADP projects. "Improper project feasibility study" is ranked second and fifth by owners and contractors, respectively. Moreover, owners ranked "Dispute on land usage" third, and contractors ranked it second. Similarly, owners placed "Ineffective planning and scheduling of project" fourth, but surprisingly it is not even considered by contractors as one of the top eight delaying factors. This shows contractors placed little importance on planning and scheduling of a project because of lack of management skills, while owners considered it among the most significant delaying factors in construction projects. The variable "Delay in finance and payments of completed work" however is ranked as the fourth most important delay factor on the list from contractors' viewpoint and 33rd from the owners' viewpoint. This shows the responsiveness of the contractor to complete the project on time and budget, which is considered a barometer to gauge the project's progress. Conversely, owners gave the least amount of importance to this factor. However, awarding the project to the lowest bid price, extreme weather conditions, and inadequate contractor experience were among the top eight most critical delaying factors as perceived by both owners and contractors.

Though somewhat different, conflicting opinions exist between the owners and the contractors, the $r_{s}$ of the ranking of owners and contractors for all factors were 0.64 and for the main groups were 0.63. The $r_{s}$ was computed for the ranking of critical delaying factors and groups shown in Tables 3 and 4 using Equation 2. Due to good agreement between the respondents in ranking factors and for the main groups, there are no differences in perceptions by owners and contractors.

\section{Discussion of Results}

This study highlighted the most significant delaying factors in the GB construction industry. This is shown by the fact that the delaying factors, whether they belong to owners or contractors, would lead to a delay in building projects. Table 3 summarizes the views of the top-ranked critical delaying factors by owners and contractors.

The findings represent only the ADP public sector building projects in GB. The top eight most combined views of critical delaying factors agreed upon by both owners and contractors are discussed below.

\subsection{Difficulties in Financing Project by Contractor}

The study found that "Difficulties in financing project by the contractor" $(\mathrm{RII}=0.702)$ was the primary significant delaying factor in GB construction projects. Sweis et al. [20] verified and found this as a topmost delaying factor in Jordan. In GB, the contractors are not financially strong and totally rely on owner "Progress payments" which ranked as the second-most critical delaying factor in this study. Contractors are not financially sound, and the credit facilities for contractors are also very limited in GB. The result of this study indicates that the contractors face financial problems, resulting in the delays in construction projects.

\subsection{Delay in Progress Payments}

In this study "Delay in progress payments" $(\mathrm{RII}=0.688)$ was the second main delaying factor because of the contractors' inability to get payments on time from owner's due to lengthy official procedures and lack of coordination between GBPWD and Planning and Finance Department (sponsoring body). Every project needs funds to get the project accomplished successfully on time and within budget, but late payments to the contractor are a serious cause of the project delay. A similar finding was also reported in a study conducted by Gündüz et al. [13] and Gunduz et al. [5] where delay in progress payments was found as a critical factor in construction projects. Moreover, the owners (government officials) confess in this study to receiving late progress payments from Finance and Planning Department, and this may cause projects to suffer. 


\subsection{Dispute on Land Usage}

Another crucial variable is "Dispute on land usage" $(\mathrm{RII}=0.680)$ which was the third most critical delaying factor. Usually, such dispute on land usage occurred in building projects because land is usually privately owned and compensation needs to be paid. Disputes may arise over payment of land compensation and rate. The delays of compensatory payments and the difference in market rates and government rates may augment the dispute because market rate is higher than the government rate and the landowner does not agree to sell the land at the government rate, causing a dispute and potential delays.

\subsection{Improper Project Feasibility Study}

This variable "Improper project feasibility study" (RII = 0.661) was ranked fourth among the critical delaying factors. It is found that project owners do not conduct thorough feasibility studies of the projects because of the geographical remoteness of project sites. At the time of execution, contractors confront serious problems in such projects. This variable may cause project time and cost overruns and causes severe delays in the construction phase of projects.

\subsection{Award Project to the Lowest Bid Price}

Both owners and contractors ranked this factor fifth $(\mathrm{RII}=0.622)$. Lowest bid price contracts are problematic in volatile markets because contractors occasionally compromise on quality to maximize their profitability. In addition, the owner needs to ensure fair scrutiny and offering rates. Moreover, contractor working experience, education, financial competence, and competent management should be reviewed. Contractors with less experience and a lack of management skills often quote relatively unachievable low bids to win the contract. The inexperienced and unprofessional lowest bidders are unaware of unexpected future issues that could affect project execution. Owners and contractors both agreed that "Award project to the lowest bid price" significantly causes project delays.

\subsection{Extreme Weather Conditions}

Both owners and contractors have ranked "Extreme weather conditions" (RII $=0.616)$ sixth on the ranking schedule. The weather condition of GB is severe, and the construction industry lacks the capacity to continue work during challenging weather conditions. Construction projects in such extreme weather conditions suffer from severe cold weather (in some areas the temperature falls to $-20^{\circ} \mathrm{C}$ ). The contractors suggested incorporating the seasonal variations in the planning process of the project as most of the regions of GB construction work were delayed for four to six months. This leads to project cost, time and schedule overruns and ultimately causes progress to be obstructed.

\subsection{Inadequate Contractor Experience}

"Inadequate contractor experience" (RII = 0.608) was the seventh most significant critical delaying factor in GB construction industry. Successful projects need qualified, well-trained, and experienced contractors. Moreover, an experienced contractors' traits include making comprehensive plans and selecting appropriate techniques for executing the construction project and accomplishing it on time, within budget and on schedule. In GB, it was found that most of the contractors have a lack of management skills and use the traditional way of construction. This study concluded that inexperienced contractors face inadequacy in planning, scheduling and controlling of the construction project, and this can cause project delays.

\subsection{Insufficient Data Collection and Survey Before Design}

This factor $(\mathrm{RII}=0.582)$ was ranked eighth in the combined ranking list. The result of the research concluded that owners do not collect enough data before the project design phase in construction projects. In most of the cases, contractors face execution problems because of ambiguous design, poor 
survey, and incomplete site investigation. After bid contractors sometimes request owners to review the design, and the contractors suggested emphasizing more location-based design instead of using a similar design for all projects. Otherwise, owners need to revise the survey and design, resulting in a significant delay.

\section{Comparison of Delay Factors of Some Selected Asian Countries}

Delays were observed as one of the significant endemic problems in the worldwide construction industry. Table 5 shows the preceding findings and comparison of delay factors by the rank of eight selected Asian countries through an analysis of the top five most important delay causes. It was concluded that financial problems faced by owners and contractors in Asian countries (Malaysia, Turkey, Vietnam, Jordan, Kuwait, Cambodia, UAE, and Iran; see Table 5) were among other similar findings found in the GB Pakistan.

Table 5. Comparison with Eight Selected Asian Countries.

\begin{tabular}{|c|c|c|c|c|c|}
\hline \multirow{2}{*}{ Countries } & \multicolumn{5}{|c|}{ Top Most Five Ranking Causes of Delay } \\
\hline & 1 & 2 & 3 & 4 & 5 \\
\hline $\begin{array}{l}\text { This study } \\
\text { (2017) }\end{array}$ & $\begin{array}{l}\text { Difficulties in } \\
\text { financing } \\
\text { project by } \\
\text { contractor }\end{array}$ & $\begin{array}{l}\text { Delay in } \\
\text { progress } \\
\text { payments }\end{array}$ & $\begin{array}{l}\text { Dispute on } \\
\text { land usage }\end{array}$ & $\begin{array}{l}\text { Improper } \\
\text { project } \\
\text { feasibility } \\
\text { study }\end{array}$ & $\begin{array}{l}\text { Award project } \\
\text { to the lowest } \\
\text { bid price }\end{array}$ \\
\hline Malaysia [24] & $\begin{array}{l}\text { Contractor's } \\
\text { improper } \\
\text { planning }\end{array}$ & $\begin{array}{l}\text { Contractor's } \\
\text { poor site } \\
\text { management }\end{array}$ & $\begin{array}{l}\text { Finance and } \\
\text { payments for } \\
\text { completed } \\
\text { work }\end{array}$ & $\begin{array}{l}\text { Inadequate } \\
\text { contractor } \\
\text { experience }\end{array}$ & $\begin{array}{l}\text { Problems with } \\
\text { subcontractors }\end{array}$ \\
\hline Turkey [36] & $\begin{array}{l}\text { Design and } \\
\text { material } \\
\text { changes }\end{array}$ & $\begin{array}{l}\text { Delay of } \\
\text { payments }\end{array}$ & $\begin{array}{l}\text { Cash flow } \\
\text { problems }\end{array}$ & $\begin{array}{l}\text { Contractor's } \\
\text { financial } \\
\text { problems }\end{array}$ & $\begin{array}{l}\text { Poor labor } \\
\text { productivity }\end{array}$ \\
\hline Vietnam [27] & $\begin{array}{l}\text { Poor site } \\
\text { management } \\
\text { and } \\
\text { supervision }\end{array}$ & $\begin{array}{l}\text { Poor project } \\
\text { management } \\
\text { assistance }\end{array}$ & $\begin{array}{l}\text { Financial } \\
\text { difficulties of } \\
\text { owner }\end{array}$ & $\begin{array}{l}\text { Financial } \\
\text { difficulties of } \\
\text { contractor }\end{array}$ & Design changes \\
\hline Jordan [20] & $\begin{array}{l}\text { Financial } \\
\text { difficulties by } \\
\text { contractor }\end{array}$ & $\begin{array}{l}\text { Too many } \\
\text { change orders } \\
\text { by the owner }\end{array}$ & $\begin{array}{l}\text { Poor planning } \\
\text { and scheduling } \\
\text { by contractor }\end{array}$ & $\begin{array}{l}\text { Presence of } \\
\text { unskilled labor }\end{array}$ & $\begin{array}{l}\text { Shortage of } \\
\text { technical } \\
\text { professionals }\end{array}$ \\
\hline Kuwait [37] & Change orders & $\begin{array}{l}\text { Financial } \\
\text { constraints }\end{array}$ & $\begin{array}{l}\text { Owner's lack of } \\
\text { experience }\end{array}$ & Materials & Weather \\
\hline Cambodia [3] & $\begin{array}{l}\text { Working } \\
\text { during rainy } \\
\text { season }\end{array}$ & Flooding & $\begin{array}{l}\text { Impact on } \\
\text { people's land } \\
\text { along the road } \\
\text { construction }\end{array}$ & $\begin{array}{l}\text { Award the } \\
\text { project to the } \\
\text { lowest bidder }\end{array}$ & $\begin{array}{l}\text { Frequent } \\
\text { equipment } \\
\text { breakdowns }\end{array}$ \\
\hline UAE [28] & $\begin{array}{l}\text { Change or } \\
\text { variation } \\
\text { orders }\end{array}$ & $\begin{array}{l}\text { Delay caused } \\
\text { by owner }\end{array}$ & $\begin{array}{l}\text { Oral change } \\
\text { orders by } \\
\text { owner }\end{array}$ & $\begin{array}{l}\text { Delay in } \\
\text { payments by } \\
\text { owner }\end{array}$ & $\begin{array}{l}\text { Low price of } \\
\text { contract due } \\
\text { to high } \\
\text { competition }\end{array}$ \\
\hline Iran [38] & $\begin{array}{l}\text { Delay in } \\
\text { progress } \\
\text { payment }\end{array}$ & $\begin{array}{l}\text { Change orders } \\
\text { by client during } \\
\text { construction }\end{array}$ & $\begin{array}{l}\text { Poor site } \\
\text { management }\end{array}$ & $\begin{array}{l}\text { Slowness in } \\
\text { decision-making } \\
\text { process by } \\
\text { client }\end{array}$ & $\begin{array}{l}\text { Financial } \\
\text { difficulties by } \\
\text { contractors }\end{array}$ \\
\hline
\end{tabular}

While comparing our data analysis with Asian countries, it was found that in all eight Asian countries, excluding Cambodia, "Financial factors" appeared to be the most repeatedly occurring factor that caused construction delays. In this study, "Difficulties in financing projects" by the contractor was ranked first, which depicts the weak financial position of contractors. If a project awarded to a contractor with financial challenges, a contract may suffer project delays. This is common in several 
countries including Vietnam (rank 4), Jordan (rank 1), Turkey (rank 4) and Iran (rank 5). However, the factor "Delay in progress payments" in this study (rank 2), in comparison trend with other countries, that is, Malaysia (rank 4), UAE (rank 4), Turkey (rank 2) and Iran (rank 1) was found. Previous studies included this study asserted that owners should be accountable for such delay factors and reported that improper budgeting, scheduling, and utilization. The study identified another factor "Dispute on land usage" in rank 3 . This is due to the land compensation dispute between landowner and project owner. For instance, landowners demand market rate and project owner offer only government rate. The same ranking trend is found in Cambodian experiences where it was ranked third. Similarly, "Improper project feasibility study" in this study was ranked fourth. The responsibility goes to project owners because improper project feasibility furthers unrealistic project schedules, estimating errors, inadequate project planning, and frequent project revision during the construction stage. Another factor in this study is "Award project to the lowest bid price" which was ranked fifth, the same ranking found in the UAE. In most of the Asian countries, traditional project management techniques are prevailing, and contractor selection criteria of low bids win, which can be seen in this study.

The contextualized discussion of other Asian countries above in comparison with this study on critical delaying factors can be seen in Table 5, which was based on RII of critical delaying factors. Therefore, it can be concluded that Asian countries face similar causes of delays in construction projects, irrespective of whether they are caused by the contractor or owner. Consequently, delays in projects equally influenced the owners, contractors and communities as well as national budgets, economic policies and other associated factors.

\section{Conclusions and Recommendations}

The main aim of this study was to determine the critical delaying factors in ADP building projects in GB, Pakistan. This study has identified critical delaying factors and main problems faced by most of the GB Pakistan construction industry. A literature review and comprehensive personal interview with professionals from the GB construction industry was conducted. A total of 52 critical delaying factors were tested and divided into eight groups. The data were collected from 58 owners and 44 contractors. The data were then computed through RII, and based on the RII values, the critical factors and groups were ranked. The top most critical delaying significant factors were concluded through ranking results based on the view of both owners and contractors. Nevertheless, some disagreement in opinions held by the public construction respondents, there is a good degree of agreement between the respondents in ranking factors (0.64) and for the main groups (0.63). A comparison with some particular previous research demonstrated that Asian countries had faced similar issues in their construction industries and that financing and on-time payments are common issues.

This study determined on ascertaining and ranking the key critical delaying factors in public construction projects. In general, overall ranking result reveals that both owners and contractors agreed and accepted their responsibility on the major causes of delays in construction projects. According to the owners, major causes of delays stem from difficulties in financing projects by contractors are due to contractor's financial status during the execution of the project. To overcome the problem of such construction delays in GB, there is a need to evaluate the financial status of the contractor before awarding the project. In contrast, delay in progress payments was the most critical delaying factor to contractors are due to on time payment issues. Further, the findings of this study indicate that top most critical delaying factors in the construction industry were related to finance and on-time payment problems. It is worth noting that the GB construction industry has funding, but there are inefficient planning and utilization of ADP funds. Moreover, other contributing factors that causing critical delays were dispute relating to land usage, improper project feasibility studies, awarding projects to the lowest bid price, extreme weather conditions, inadequate contractor experience, insufficient data collection, and surveying before design. To overcome and mitigate the identified causes of critical delaying factors in the construction industry in GB, the following recommendations are suggested by both owners and contractors and for further explanation see Appendix A: 
i. The Planning and Finance Department should transfer all the requisite funds of approved ADP projects to the executive engineer departmental account before awarding the project rather than in a quarterly fund release. This will hasten the progress payments to the contractors resulting in no funds lapsing.

ii. The owner should conduct proper supervision and monitoring of contractors on a weekly basis so that it will improve the work in progress, quality control and performance measurement of the project.

iii. The owners should focus on customized procedures to cross-check the documentary evidence provided by contractors for projects, including the contractors' documents and capabilities (education, financial, experience, personnel, and equipment), before awarding the project to the lowest bidder.

iv. The owner should hand over the land free from compensatory arrangements, legal issues, disputes and litigation to the contractors for project execution.

v. The owner should avoid guesswork and focus on realistic project designs after visiting the site before designing the project.

vi. The contractor should properly organize effective and efficient scheduling, monitoring and controlling to improve project performance to mitigate construction delays.

Identification and ranking of delaying factors from most significant to least one would help to monitor deficiencies and possible improvement areas and avoided delay by considering the significant factors in future, paying greater attention and taking the required actions recommended in this study.

Acknowledgments: This study was supported by the National Natural Science Foundation of China with Grant No. 71372085. The authors would like to thanks Iqtidar Hussain and Adnan Haider Khoja for their great help and support for the accomplishment of the data collection and for the questionnaires' completion. Additionally, the valuable comments and suggestions from the editor and all the reviewers are highly appreciated.

Author Contributions: Shahid Hussain and Fangwei Zhu formulated the research design and organized most of the data. The analysis was conducted by Shahid Hussain, Zaigham Ali and Hassan Danial Aslam. Shahid Hussain, Zaigham Ali, and Abasal Hussain collected the data from GB, Pakistan. Shahid Hussain wrote the manuscript.

Conflicts of Interest: The authors declare no conflict of interest.

\section{Appendix A}

In Pakistani Public construction industry context Planning and Finance Department transfer funds to Project Manager account on a quarterly basis, so we suggest that the whole project funds should transfer to Project Manager account after the bid is awarded to the contractor. It will overcome the payments delay to contractors or service providers. Also, when the funds are transferred on a quarterly basis, there is a great chance of funds lapsing.

Project bidding and awarding to contractors or service providers means transferring the risk to the parties (contractors) through contracting or shifting the financial risk. Also, transferring risks to the contractors or service providers will eventually escalate the cost of the project due to the contingency allowance available. When the risk is transferred, the owner should proper supervision the service providers to check the project progress on weekly basis rather than on monthly basis. On actual realities, the Project Manager assistant visits the sites on monthly basis and just make a report whatever the contractors or service providers tells them.

Most of the project designs are made by the designer without visiting the actual project sites. We suggest them to visit the project sites and avoid guess works before bidding the project. It will enhance the project performance and minimizing the cause of delays during execution phase.

Most of the contractors in GB do not know the proper planning, appropriate construction methods, and scheduling of the project. They construct the project using (their) traditional way and many mistakes during the execution phase of the project which is ultimately comes to construction project delay. Owner should arrange workshops and seminars for contractors or service providers for their 
professional development on a periodic basis, as contractors need more technical, analytical, risk analysis, and leadership skills to better achieve the organizational goals.

\section{References}

1. Alzahrani, J.I.; Emsley, M.W. The Impact of Contractors' Attributes on Construction Project Success: A Post Construction Evaluation. Int. J. Proj. Manag. 2013, 31, 313-322. [CrossRef]

2. Aibinu, A.A.; Jagboro, G.O. The Effects of Construction Delays on Project Delivery in Nigerian Construction Industry. Int. J. Proj. Manag. 2002, 20, 593-599. [CrossRef]

3. Santoso, D.S.; Soeng, S. Analyzing Delays of Road Construction Projects in Cambodia: Causes and Effects. J. Manag. Eng. 2016, 32, 1-11. [CrossRef]

4. Asadi, A.; Alsubaey, M.; Makatsoris, C. A Machine Learning Approach for Predicting Delays in Construction Logistics. Int. J. Adv. Logist. 2015, 4, 115-130. [CrossRef]

5. Gunduz, M.; Nielsen, Y.; Ozdemir, M. Fuzzy Assessment Model to Estimate the Probability of Delay in Turkish Construction Projects. J. Manag. Eng. 2013, 31, 1-14. [CrossRef]

6. Hussain, S.; Zhu, F.; Ali, Z.; Xu, X. Rural Residents' Perception of Construction Project Delays in Pakistan. Sustainability 2017, 9, 2108. [CrossRef]

7. Assaf, S.A.; Al-Hejji, S. Causes of Delay in Large Construction Projects. Int. J. Proj. Manag. 2006, 24, 349-357. [CrossRef]

8. Lo, T.Y.; Fung, I.W.H.; Tung, K.C.F. Construction Delays in Hong Kong Civil Engineering Projects. J. Constr. Eng. Manag. 2006, 132, 636-649. [CrossRef]

9. Kaliba, C.; Muya, M.; Mumba, K. Cost Escalation and Schedule Delays in Road Construction Projects in Zambia. Int. J. Proj. Manag. 2009, 27, 522-531. [CrossRef]

10. Kim, S.Y.; Tuan, K.N.; Luu, V.T. Delay Factor Analysis for Hospital Projects in Vietnam. KSCE J. Civ. Eng. 2016, 20, 519-529. [CrossRef]

11. Ye, G.; Jin, Z.; Xia, B.; Skitmore, M. Analyzing Causes for Reworks in Construction Projects in China. J. Manag. Eng. 2014, 31, 1-9. [CrossRef]

12. Khoshgoftar, M.; Bakar, A.H.A.; Osman, O. Causes of Delays in Iranian Construction Projects. Int. J. Constr. Manag. 2010, 10, 53-69. [CrossRef]

13. Gündüz, M.; Nielsen, Y.; Özdemir, M. Quantification of Delay Factors Using the Relative Importance Index Method for Construction Projects in Turkey. J. Manag. Eng. 2013, 29, 133-139. [CrossRef]

14. Abdul-Rahman, H.; Berawi, M.A.; Berawi, A.R.; Mohamed, O.; Othman, M.; Yahya, I.A. Delay Mitigation in the Malaysian Construction Industry. J. Constr. Eng. Manag. 2006, 132, 125-133. [CrossRef]

15. Yang, J.-B.; Ou, S.-F. Using Structural Equation Modeling to Analyze Relationships among Key Causes of Delay in Construction. Can. J. Civ. Eng. 2008, 58, 321-323. [CrossRef]

16. Yang, J.; Kao, C. Critical Path Effect Based Delay Analysis Method for Construction Projects. Int. J. Proj. Manag. 2011, 30, 385-397. [CrossRef]

17. Marzouk, M.M.; El-Rasas, T.I. Analyzing Delay Causes in Egyptian Construction Projects. J. Adv. Res. 2014, 5, 49-55. [CrossRef] [PubMed]

18. El-razek, M.E.A.; Bassioni, H.A.; Mobarak, A.M. Causes of Delay in Building Construction Projects in Egypt. J. Constr. Eng. Manag. 2008, 134, 831-841. [CrossRef]

19. Odeh, A.M.; Battaineh, H.T. Causes of Construction Delay: Traditional Contracts. Int. J. Proj. Manag. 2002, 20, 67-73. [CrossRef]

20. Sweis, G.; Sweis, R.; Abu Hammad, A.; Shboul, A. Delays in Construction Projects: The Case of Jordan. Int. J. Proj. Manag. 2008, 26, 665-674. [CrossRef]

21. Al-Momani, A.H. Construction Delay: A Quantitative Analysis. Int. J. Proj. Manag. 2000, 18, 51-59. [CrossRef]

22. Frimpong, Y.; Oluwoye, J.; Crawford, L. Causes of Delay and Cost Overruns in Construction of Groundwater Projects in a Developing Countries; Ghana as a Case Study. Int. J. Proj. Manag. 2003, 21, 321-326. [CrossRef]

23. Al-Kharashi, A.; Skitmore, M. Causes of Delays in Saudi Arabian Public Sector Construction Projects. Constr. Manag. Econ. 2009, 27, 3-23. [CrossRef]

24. Sambasivan, M.; Soon, Y.W. Causes and Effects of Delays in Malaysian Construction Industry. Int. J. Proj. Manag. 2007, 25, 517-526. [CrossRef] 
25. Aziz, R.F.; Abdel-Hakam, A.A. Exploring Delay Causes of Road Construction Projects in Egypt. Alex. Eng. J. 2016, 1, 1-25. [CrossRef]

26. Hwang, B.; Zhao, X.; Yi, S. Identifying the Critical Factors Affecting Schedule Performance of Public Housing Projects. Habitat Int. 2013, 38, 214-221. [CrossRef]

27. Le-Hoai, L.; Lee, Y.D.; Lee, J.Y. Delay and Cost Overruns in Vietnam Large Construction Projects: A Comparison with Other Selected Countries. KSCE J. Civ. Eng. 2008, 12, 367-377. [CrossRef]

28. Zaneldin, E.K. Construction Claims in United Arab Emirates: Types, Causes, and Frequency. Int. J. Proj. Manag. 2006, 24, 453-459. [CrossRef]

29. Aibinu, A.A.; Odeyinka, H.A. Construction Delays and Their Causative Factors in Nigeria. J. Constr. Eng. Manag. 2006, 132, 667-677. [CrossRef]

30. Olawale, Y.; Sun, M. PCIM: A Project Control and Inhibiting-Factors Management Model. J. Manag. Eng. 2013, 29, 60-70. [CrossRef]

31. Akogbe, R.-K.T.M.; Feng, X.; Zhou, J. Importance and Ranking Evaluation of Delay Factors for Development Construction Projects in Benin. KSCE J. Civ. Eng. 2013, 17, 1213-1222. [CrossRef]

32. Doloi, H.; Sawhney, A.; Iyer, K.C.; Rentala, S. Analysing Factors Affecting Delays in Indian Construction Projects. Int. J. Proj. Manag. 2012, 30, 479-489. [CrossRef]

33. Assaf, S.A.; Al-Khalil, M.; Al-Hazmi, M. Causes of Delay in Large Building Construction Projects. J. Manag. Eng. 1995, 11, 45-50. [CrossRef]

34. Kottegoda, N.T.; Rosso, R. Applied Statistics for Civil and Environmental Engineers; McGraw-Hill: New York, NY, USA, 1997.

35. Hameed, B.A.; Woo, S. Risk Importance and Allocation in the Pakistan Construction Industry: A Contractors' Perspective. KSCE J. Civ. Eng. 2007, 11, 73-80. [CrossRef]

36. Kazaz, A.; Ulubeyli, S.; Tuncbilekli, N.A. Causes of Delays in Construction Projects in Turkey. J. Civ. Eng. Manag. 2012, 18, 426-435. [CrossRef]

37. Koushki, P.A.; Al Rashid, K.; Kartam, N. Delays and Cost Increases in the Construction of Private Residential Projects in Kuwait. Constr. Manag. Econ. 2005, 23, 285-294. [CrossRef]

38. Pourrostam, T.; Ismail, A. Causes and Effects of Delay in Iranian Construction Projects. IACSIT Int. J. Eng. Technol. 2012, 5, 450-456. [CrossRef]

(C) 2018 by the authors. Licensee MDPI, Basel, Switzerland. This article is an open access article distributed under the terms and conditions of the Creative Commons Attribution (CC BY) license (http:/ / creativecommons.org/licenses/by/4.0/). 